液体クロマトグラフィーによる各種セルロース繊維の細孔分析

\author{
信州大学繊維学部 柳内雄一・清水義雄 \\ 県立新潟女子短大 佐々木博昭・吞海信雄
}

\title{
Analysis of the Pore Structure of Various Cellulosic Fibers by Liquid Chromatography
}

\author{
Yuichi Yanai $^{* 1}$, Yoshio Shimizu ${ }^{* 1}$,Hiroaki Sasaki ${ }^{* 2}$, and Nobuo Donkai ${ }^{* 2}$ \\ ${ }^{*}$ Graduate School of Science and Technology, Shinshu University, Ueda, Nagano 386-8567, Japan \\ ${ }^{* 2}$ Niigata Women's College, 471 Ebigase, Niigata 950-0806, Japan
}

\begin{abstract}
In the analytical method for ascertaining the pore structure of cellulosic fibers by liquid chromatography through drawing a bundle of threads into a column[4], the preparation procedure and the type of specimens deeply influence the results. In the case of Tencel, rayon and linen, the permeability limit is clear but, in the case of cotton treated with liquid ammonia, the permeability limit is difficult to discover. To solve this problem, a method of making each thread free and removing twists before bringing the threads together as a bundle is useful. The permeability limit for Tencel, rayon, linen and cotton are found to have a PEG molecular diameter of 5.8nm and for liquid ammonia treated cotton $5.8 \mathrm{~nm}$, or $4.9 \mathrm{~nm}$, through the improved method.
\end{abstract}

(Received 29 October, 2004; Accepted 20 December, 2004)

\section{1. 緒 言}

分子量既知のポリエチレングリコール(PEG)等を溶質 とする液体クロマトグラフィーによって膨潤時のセルロ 一ス繊維の細孔分析を行う方法には, Rowland 等によるわ た状の繊維をカラムに詰める方法 [1], Bredereck 等による 円板状の布を詰める方法 [2], Ladisch 等による筒状に巻い た布を詰める方法 [3]等が開発されている.

このうち Bredereck 等[2]は円板状の布による方法によ って, 液体アンモニア加工による細孔分布の変化のデータ を測定している. Fig.1 はその一例である（Bredereck 等 [2] 450 頁).

筆者等はセルロース繊維の性能を顕著に向上させる液 体アンモニア加工の効果が, どの様な瀻維構造変化による ものかを液体クロマトグラフィーの手法で明らかにした いと考えた. しかし, Fig. 1 を含む Bredereck 等による各 種データでは排除限界が明確には示されていない. グラフ から判断すると直径 $10 \mathrm{~nm}$ 以上のある一定の值を共通の排 除限界とみなしていると推察される. また, 試料作成に特 殊な装置が必要であるため, 当方での検討が困難であった.

その後, 操作が容易な方法として糸を束にしてカラム に引き込む手法が笠原等 [4]によって考案された.

そこで笠原等の方法によって液体アンモニア処理綿布 を初めとする各種セルロース繊維の分析を行い, 加工によ る微細構造変化の分析手法としての有用性を検証した.

その過程で, 試料の種類と作成方法が分析結果に大き
く影響することが分かり,試料作成方法を改良した.また, 溶出曲線から排除限界を判定する方法について考察し, 変 曲点の解釈が重要であるとの結論を得た。

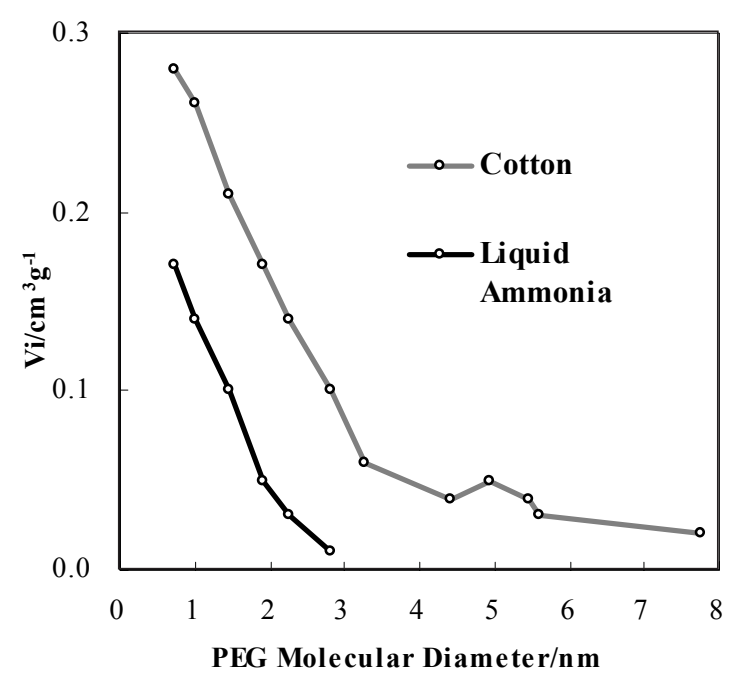

Fig. 1 Pore volume of cotton, bleached and after liquid ammonia treatment (K. Bredereck, 1991) [2]

\section{2. 実 験}

\section{1 試料の作成}

試料として Table 1 に示す綿 (品名 No. 5747), 通常テン 
セル, A100 テンセル, A200 テンセル, レーヨン, リネン, バナナ綿 30/70 混紡繊維及び特に準備した単一品種綿を 使った. いずれも紡績糸であり, 綿, レーヨン, リネンは 織物, その他は糸である. 加工は漂白上り, 液体アンモニ ア処理, 樹脂加工, 高圧スチーム処理等である.

Table 1 Characterization of Samples

\begin{tabular}{lcl}
\hline \multicolumn{1}{c}{ Samples } & $\begin{array}{c}\text { Yarn } \\
\text { count }\end{array}$ & $\begin{array}{c}\text { State of } \\
\text { samples }\end{array}$ \\
\hline Cotton (No. 5747) & $50 / 1$ & Fabric \\
Tencel & $40 / 1$ & Yarn \\
Rayon & $30 / 1$ & Fabric \\
Linen & $21 / 1$ & $\prime \prime$ \\
Banana/Cotton 30/70 & $20 / 1$ & Yarn \\
American Pima 100\% & $5 / 1$ & $\prime \prime$ \\
Aspero $100 \%$ & $16 / 1$ & $\prime \prime$ \\
San Joaquin $100 \%$ & $30 / 1$ & $\prime \prime$ \\
\hline
\end{tabular}

分析用試料は糸又は布の経糸長さ約 $40 \mathrm{~cm}$ を採取し, $4 \mathrm{~g}$ 弱 $\left(20^{\circ} \mathrm{C}, 65 \%\right)$ を平行に並べた. これを一夜蒸留水に浸 漬して膨潤させてから内径 $6 \mathrm{~mm}$, 長さ $30 \mathrm{~cm}$ のステンレス カラムに引き込み, 糸束の両端を強く引いて緩みを除いた 後, 両端を切り落とした. なお、充填量は笠原等の実験に 倣ったが, 送液圧力の関係で若干減らした. 乾燥体積とし てカラム体積の約 30\%である．また充填量は一連の測定 において同一であることが望ましいが、作業方法の制約に より若干の差が生ずるのは避けられない.

\section{2 測定条件}

高速液体クロマトグラフィーは島津製作所 HPLC システ ム CLASS-LC10（検出器 DID-10A，ポンプ LC-10AD，デガッ サーDGU-12A，オーブン CT0-10AC, バスモジュール CBM-10A)を使用した. プローブとして分子量 106 から 960, 000 までのジーエルサイエンス社製ポリエチレングリコ ール（PEG）を用いた. PEG 溶液の濃度については笠原等 [4]と木水等 $[6]$ は $0.1 \mathrm{wt} \%$ としいるが, Bredereck 等 $[5]$ 及び Rowland 等 [1] はそれぞれ 1.0\%としている. 本報では 安定したピークを得るため、各々 $0.3 \mathrm{wt} \%$ 溶液とした. 注入 量 $20 \mu \mathrm{l}$, 流速 $0.5 \mathrm{ml} / \mathrm{min}$, 温度 $30^{\circ} \mathrm{C}$ で溶出曲線を採 取し、ピーク溶出時間と流速の積からカラム接続部のデッ ドボリュームを除いて溶出量を算出した. 測定の前に流速 $0.5 \mathrm{~m} \ell / \mathrm{min}$ で一夜蒸留水を流して試料を安定させた。

\section{3 細孔容積と分布の算出}

溶出容積から次式 (1) により細孔容積 Vi を算出した.

$$
\mathrm{Vi}=(\mathrm{Ve}-\mathrm{Vm}) / \mathrm{W}
$$

ここで Ve はある分子量に対応する溶出容積, Vm は分 子量が大きくて細孔に浸入できなくなった時点（排除限 界）での溶出量即ち移動層容積，W は試料の絶乾重量を 夫々示す. Vi はある分子量以上の PEG 分子が浸入できる 単位重量当りの細孔容積を意味する.

PEG 分子の直径 D (nm) の算出には Bredereck 等[5]と
同様次式（2）を用いた。

$$
\mathrm{D}=0.174 \mathrm{M}^{0.40}
$$

また，細孔の分布を知るため Vi の変化率

$$
\mathrm{V}=-\mathrm{dVi} / \mathrm{dD}
$$

を計算した.なお笠原等[4]は

$$
\mathrm{k}^{*}=(\mathrm{Ve}-\mathrm{Vm}) /(\mathrm{Vm} \times \mathrm{Vswell})
$$

なるファクターを導入したが，本報では従来の文献值 と比較するため上述の Vi を使用した.

\section{3. 結果と考察}

\section{1 綿液体アンモニア処理品の細孔分析}

Bredereck 等の結果（Fig. 1) をトレースするため, 綿 の漂白上りと液体アンモニア処理品の細孔分析を行った. 液体アンモニア処理は生産用の連続処理機で行った. 溶出 時間のグラフを Fig. 2 に示す. 漂白上りの場合は水平に 近い部分が現れるが, 液体アンモニア処理品の場合は, 水 平部分が現れないと共に, 分子量 10,000 以上で曲線が急 傾斜で低下している.この様に排除限界の判定が難しいた め, Fig. 2 から排除限界を分子量 960,000（直径 43.0nm） と仮定して Vi を計算したものが Fig. 3A である. このグラ フはFig. 1 に示す Bredereck等のグラフとは結果が全く異 なり, 液体アンモニア処理品の方が直径のほぼ全範囲に亘 って細孔容積が多い. 従って何等かの測定上の問題点があ ると考えた。なお木水等 $[6]$ も高圧処理した綿及びレーヨ ンの液体クロマトグラフィーによる細孔分析において、未 処理の綿及びレーヨン並びに高圧処理した綿の排除限界 は明確でないと報告している.

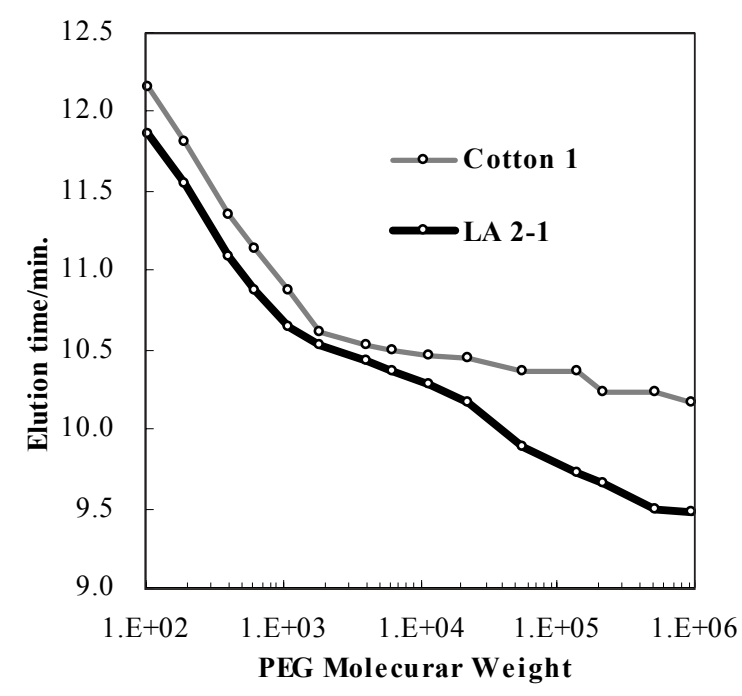

Fig. 2 Elution time of cotton, bleached and after liquid ammonia treatment (Ammonia Unit No.2). 


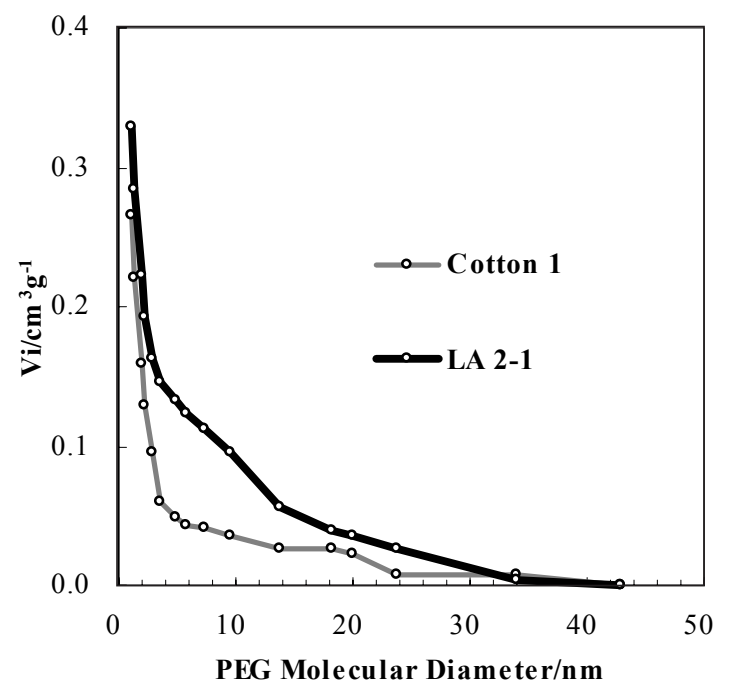

Fig. 3A Pore volume of cotton, bleached and after liquid ammonia treatment (Ammonia Unit No. 2).

\section{2 各種テンセルの溶出曲線}

綿の液体アンモニア処理品の細孔分析結果が文献值と 一致しない原因を挆るため, 綿以外のセルロース繊維とし てテンセルの分析を試みた. テンセルには通常のテンセル の他にフィブリル化を防止するために架橋浏で変性した 2 種類のテンセルがある.これら 3 種のテンセルの内容を Table 2 に示す（テンセル説明会資料による）．試料はいず れも漂白上がり 40 単糸の綛糸である.

Table 2 Characterization of Tencel.

\begin{tabular}{l|lll}
\hline & $\begin{array}{l}\text { Tencel } \\
\text { Standard }\end{array}$ & Tencel A-100 & Tencel A-200 \\
\hline Fibrillation & Fibrillating & Non-fibrillating & Non-fibrillating \\
\hline $\begin{array}{l}\text { Crosslinking } \\
\text { agent }\end{array}$ & $\begin{array}{l}\text { No } \\
\text { treatment }\end{array}$ & Formaldehyde & $\begin{array}{l}\text { Dichlorotriazine } \\
\text { Sodium Salt }\end{array}$ \\
\hline
\end{tabular}

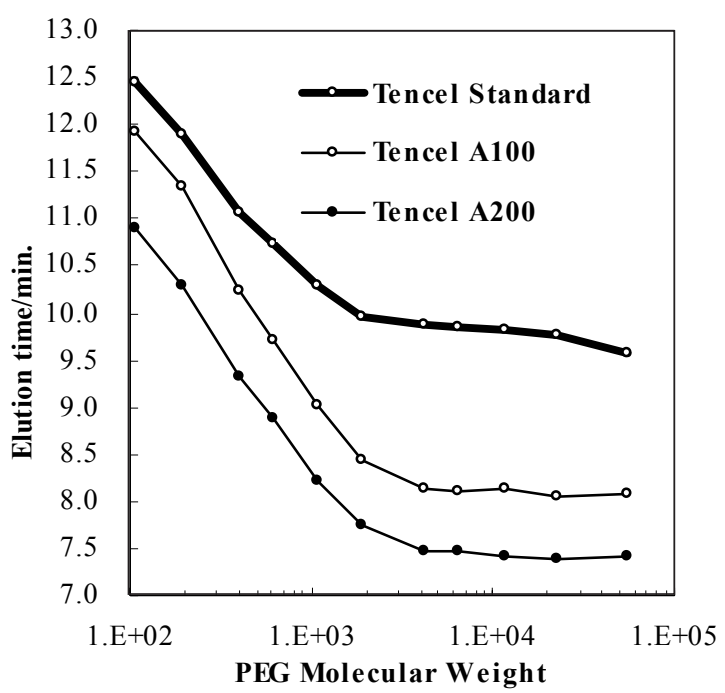

Fig. 4 Elution time of Tencel.
Fig. 4 に示す様に, 綿の液体アンモニア処理品と違い溶 出曲線は PEG 分子量 6,450 付近以降がほぼ水平となる. 更に詳細に観察すると，テンセル通常品とテンセル A200 は分子量 4,120 から 6,450 でほぼ水平となり, 6,450 で少し 下降に転じて変曲点を示す．テンセル A 100 は 6,450 で局 部的な最低值となった後わずかに上下する.

\section{3 レーヨンの溶出曲線}

テンセルの場合溶出曲線に水平部分又は変曲点が現れ る理由が, 綛糸であるためか再生緘維であるためか分らな いため, 別の再生セルロース繊維であるレーヨンの細孔分 析を試みた。試料は 30 単糸の織物である.

Fig. 6 はレーヨン及びその $180^{\circ} \mathrm{C} 5$ 分の高圧スチーム処 理後の溶出曲線である. 二つの曲線共に PEG 分子量 4,120 と6,450 の間でほぼ水平となり，6,450 以降は低下を始め 6,450 が変曲点となる。

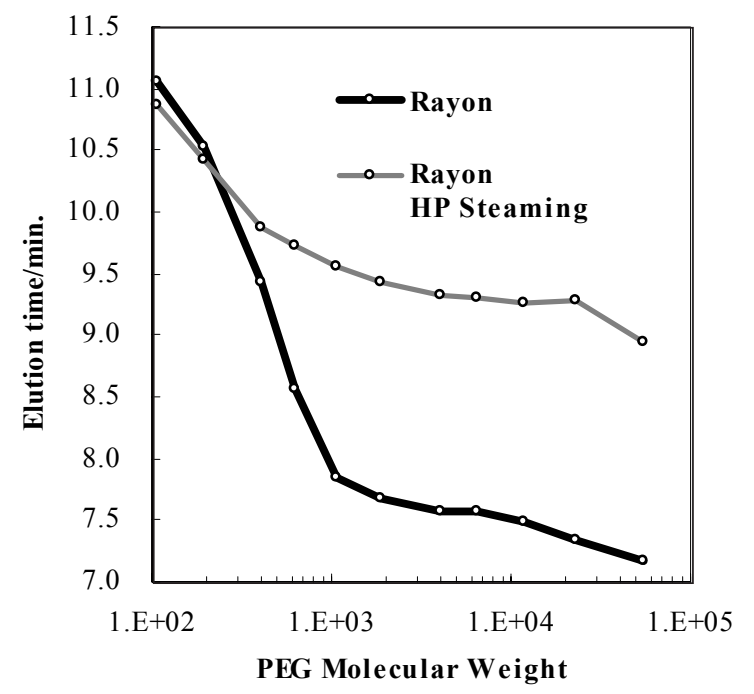

Fig. 5 Elution time of Rayon, bleached and after HP steaming.

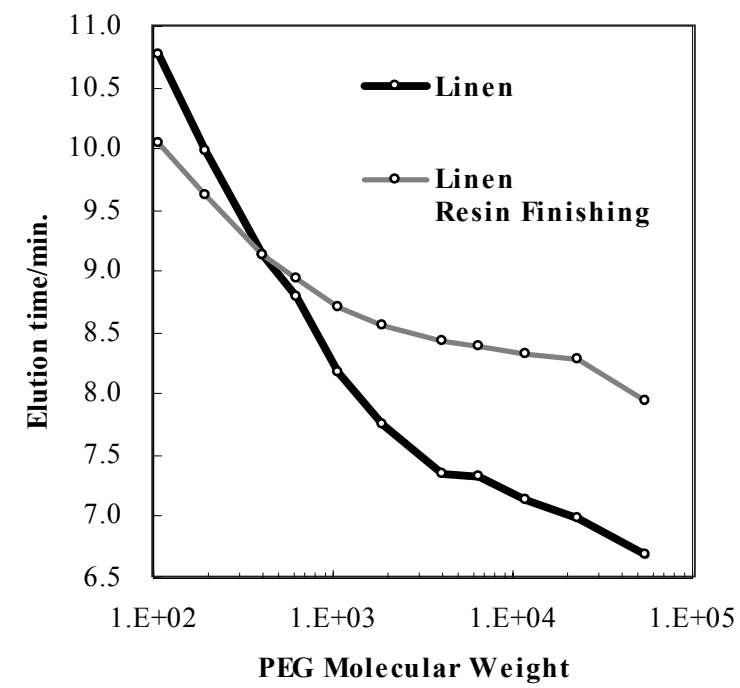

Fig. 6 Elution time of linen, bleached and after resin finishing. 


\section{4 リネンの溶出曲線}

続いて綿以外の天然セルロース繊維としてリネンおよ びその樹脂加工後の細孔分析を試みた。試料は綿換算 21 番手単糸の織物である. 樹脂加工はジメチロールジヒドロ キシエチレン尿素系樹脂により常法で実施した. Fig.6は その溶出曲線である. PEG 分子量 4,120 と 6,450 の間でほ ぼ水平となり, 6,450 で変曲点を示した後は, かなり大き く低下している

\section{5 溶出曲線における変曲点と繊維外空隙の関係}

テンセル, レーヨン, リネンのいずれの場合も溶出曲 線に水平部分またはほぼ水平な部分に続く変曲点が現れ る. また綛糸から試料を採取したテンセルと違い織物から 経糸を採取したレーヨン, リネンでは変曲点以降の低下が 大きい.

この水平部分の現れ方及びそれ以降の状況の違いの原 因は, 繊維外部に形成された空隙にあり, これが溶出曲線 に影響するのではないかと考えた. 即ち, 糸の束として集 められた繊維は相互に完全に密着していることはあり得 ず, 必ず繊維間に空隙が存在する. そしてこの空隙は密着 に近い部分の $\mathrm{nm}$ 単位の大きさから間隔の大きな $\mu \mathrm{m}$ 単位 の大きさまで分布している筈である. 従って液体クロマト グラフィーによる溶出曲線は比較的小さな繊維内部の細 孔の曲線と比較的大きな繊維外部の空隙の曲線を加算し たものとなる. 変曲点は二つの曲線が重なった結果現れる. 変曲点以前の曲線は主に䋊維内部の小さな細孔の分布を 表わし、変曲点以降の溶出曲線は, 繊維外部空隙の大きな 細孔の分布を反映したものと解釈される. 従って, 水平部 分が明らかに現れた場合は水平になった最初の点, 変曲点 が現れた場合は変曲点を排除限界と判定するのが妥当で あると考えた。

なお, テンセルの場合水平部分が明瞭であるのは綛糸 であったためと考えられる. 即ち, 織物では経糸と緯糸の 交差によって各々の糸にはクリンプが形成される. その織 物から糸を抜いた場合, クリンプが多少度残るので, これ を束ねた場合, 糸の間に空隙が形成され易い. テンセルは 綛糸であるためクリンプが少ないのに対し, レーヨンとリ ネンは織物から経糸を採取しているためクリンプが多く 繊維外部の空隙が多かったものと思われる.

\section{6 細孔容積 Vi の算出}

変曲点を排除限界とみなす方式によりテンセル等の細 孔容積 Vi を計算した. Fig. 7 はテンセルの細孔容積 Vi と PEG 分子直径との関係を示す. 前述の理由から, テンセ ル 3 種とも $\mathrm{PEG}$ 分子量 6,450 （直径 $5.8 \mathrm{~nm}$ ）を排除限界と 判定した. 架橋によってフィブリル発生を防いだとされる テンセル A100 と A200 は, 通常テンセルより膨潤時の細 孔含有量が多い.これは膨潤状態で架橋が形成されたため と推定される.

Fig. 8 はレーヨンの細孔容積を示す. テンセルと同じく 変曲点である $\mathrm{PEG}$ 分子量 6450 （直径 5.8nm）を排除限界 と判定した. 高圧スチーム処理により, レーヨンの細孔が
減少する変化が明瞭である

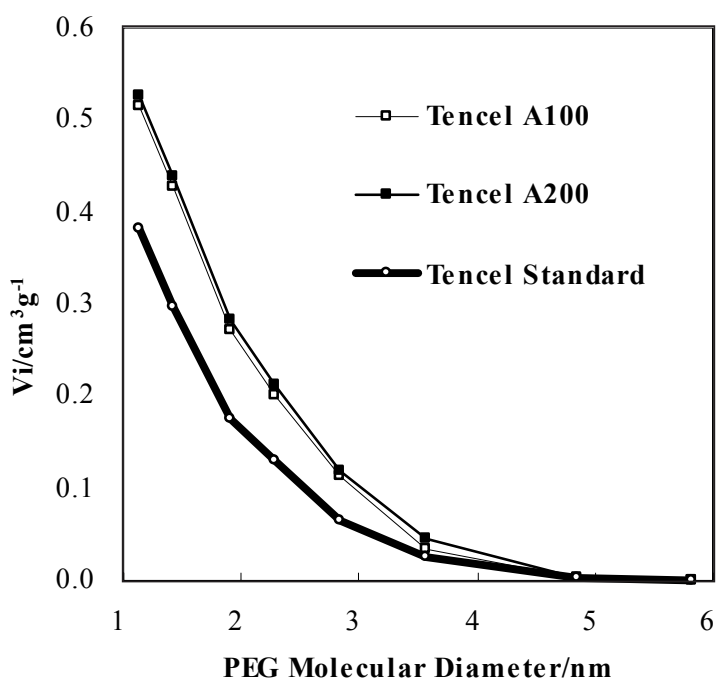

Fig. 7 Pore volume of Tencel.

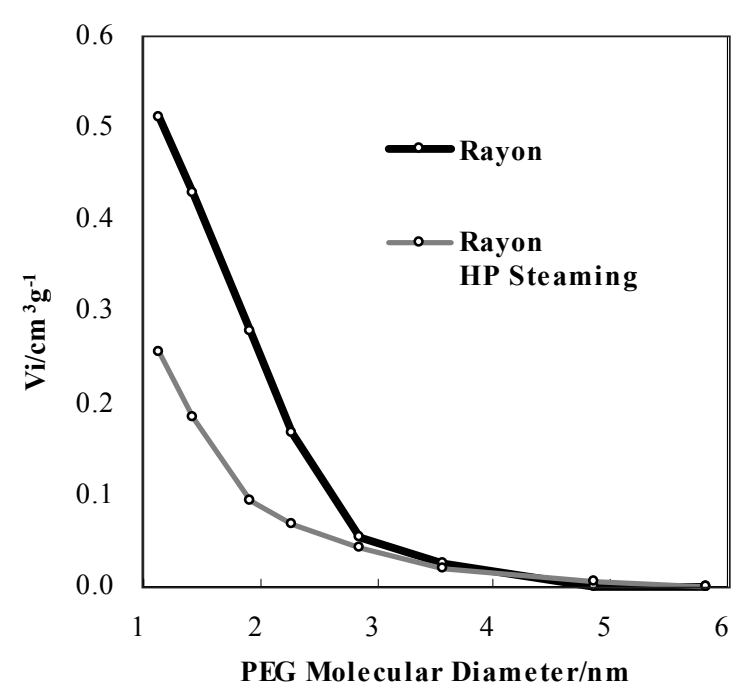

Fig. 8 Pore volume of Rayon.

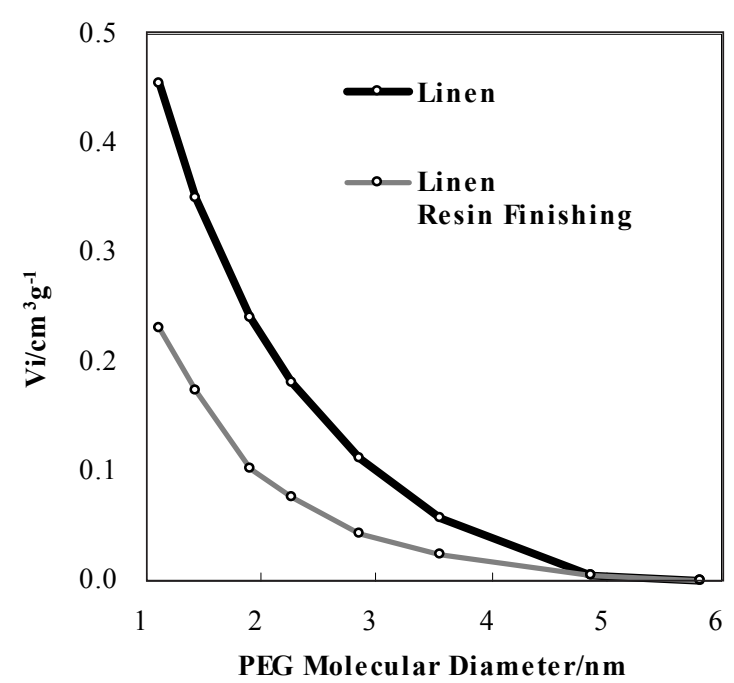

Fig. 9 Pore volume of Linen. 
Fig. 9 はリネンの細孔容積を示す. 排除限界は樹脂加工 あり,なし共に変曲点から PEG 分子量 6,450 と判定した.

樹脂加工により乾燥状態の細孔分布が固定されるため か, 膨潤時の細孔体積は明らかに減少している.

この様に変曲点を排除限界と判定すると, テンセル, レーヨン, リネンと云う異なるセルロース繊維の排除限界 が共通して PEG 分子量 6,450（直径 5.8nm）となることは 注目すべき現象である.

\section{7 綿液体アンモニア処理品の試料作成方法の改良}

続いて綿液体アンモニア処理品の溶出曲線について考 察した.この試料はレーヨン, リネンと同様に織物から経 糸を採取しているが, 打込みが多い織物 $(148 \times 80)$ であ るためクリンプが多い. また別の要素として細番手 (50/1) であるため, レーヨン (30/1), リネン (21/1) よりも単位 長さ当りの糸の撚りが多い. 布から経糸を抜く際は数本を 一緒に抜くが, 綿液体アンモニア処理品の場合は, 抜いた 後, そのまま重ねると撚りのために数本が軽く撚られて 1 本の太い糸の様になる傾向が顕著であった.

そこで経糸を抜いたあと, 1 本毎にフリーな状態にして 自然に戻る程度に撚りを解除し, その後極力平行に並べる 方法を試みた. Fig.10 は Fig. 2 に示したと同じ綿液体アン モニア処理品の試料作成方法の異なる試料についての溶 出曲線である. 糸の撚りに考慮をせず整列状態が十分でな いカーブ LA 2-1 の場合, グラフの傾斜が急で, しかも一 方的に低下を続けるため, 排除限界を決めることができな い. これに対し糸の然りを除き, 配列をよくするとカーブ LA 2-2 の様に水平に近い部分に続く変曲点が現れた. こ こを排除限界とすると $\mathrm{PEG}$ 分子量 6,450 の点となった.

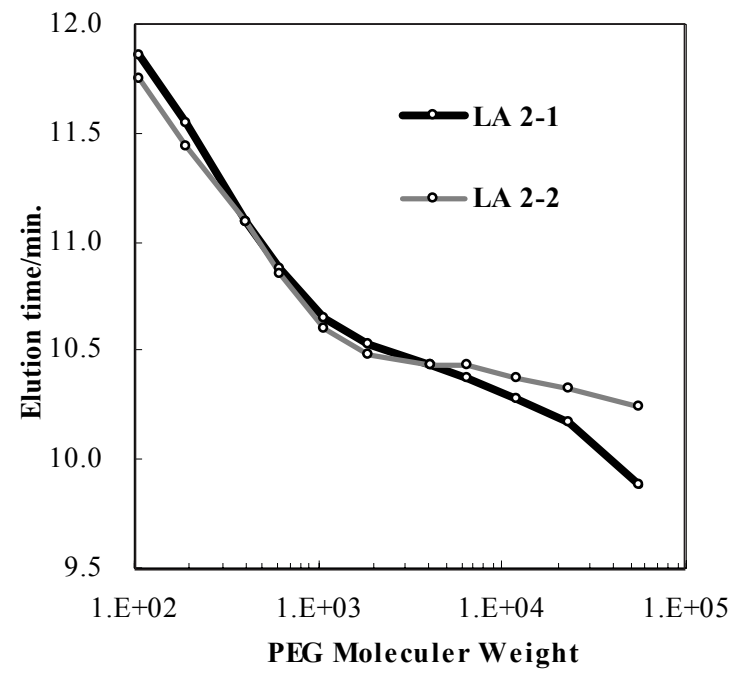

Fig. 10 Elution time of cotton, bleached and after liquid ammonia treatment (Ammonia Unit No. 2). LA 2-1 : Not well arranged, LA 2-2 : Well arranged.

Fig. 11 は液体アンモニア加工条件が Fig. 10 と異なる試 料についての測定結果である. Fig. 10 同様撚りを除かな い試料 LA4-1 は水平部分の現れない傾斜の急なカーブと なるが, 撚りを除くと LA4-3 の様に水平部分が現れるか,
LA4-2 の様に変曲点が現れ, 排除限界はいずれも PEG 分 子量 4,120（直径 4.86nm） と判定される. 3 本の溶出曲線 の位置が少しづつ違うのは, LA4-1 の試料重量が 3.63g, LA4-2 が 3.54g， LA4-3 が 3.40g と少しづつ違うことと、 充填状態の違いによるものと思われる.

また溶出曲線の傾斜が急であることは, 細孔容積が多 いことを意味するので, 配列のよくない試料 LA4-1 では 排除限界以下の低分子量の範囲でも繊維内部以外の空隙 の量が LA4-2 や LA4-3 より多いと解釈される.

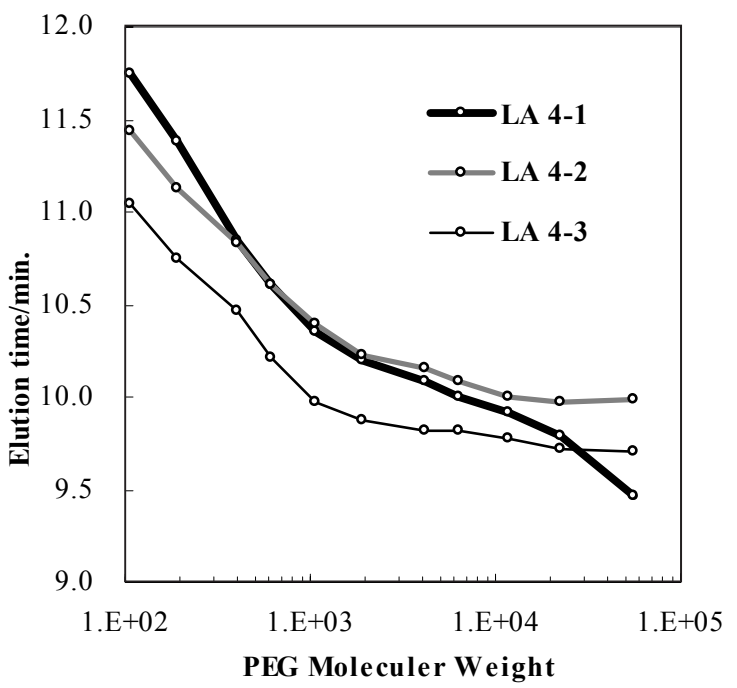

Fig. 11 Elution time of cotton after liquid ammonia treatment (Ammonia Unit No. 4). LA 4-1: Not well arranged, LA 4-2, 4-3:Well arranged respectively.

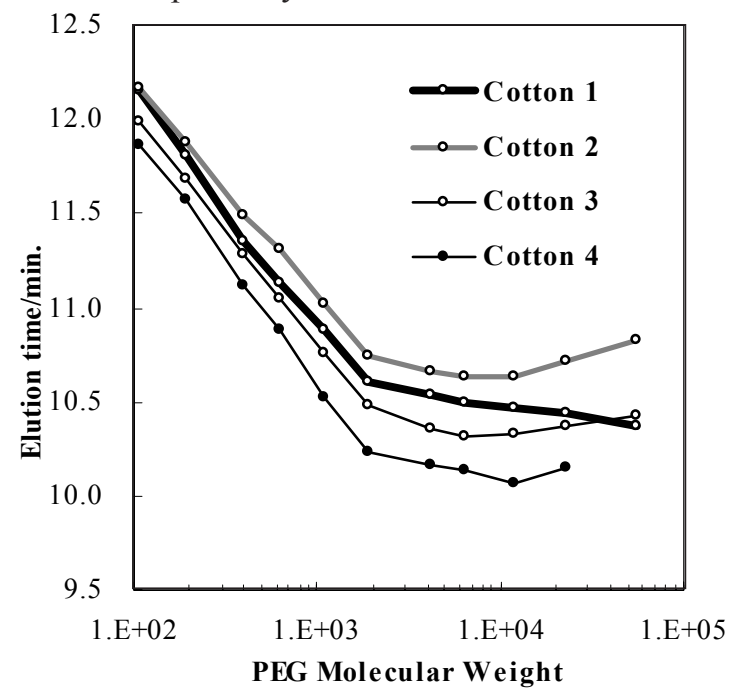

Fig. 12 Elution time of bleached cotton. Cotton 1: Not well arranged, Cotton 2, 3, 4 : Well arranged respectively.

Fig.12 は漂白上りの綿から繰り返して測定試料を作成 し, 溶出時間を測定したものである. Cotton 1 は撚りを除 かなかったもの, Cotton 2, 3, 4 は撚りを除いたものである. Cotton 2 と Cotton 3 では最低值が現れる. Cotton 4 の場合 は変曲点が現れる. いずれも共通して PEG 分子量 6,450 
のところで変化が起こっている. 変曲点以降の状況が液体 アンモニア処理品と異なるのは, 繊維外部空隙の状況の違 いによるものと思う.

最低值及び変曲点を排除限界とすると $\mathrm{PEG}$ 分子量 6,450 の点と判定される. この值はテンセル, レーヨン, リネンと同一となる. 後述する様に, 綿の品種が異なって も，排除限界は PEG 分子量 6,450 となる. この排除限界 6,450 即ち直径 $5.8 \mathrm{~nm}$ の数值は阿部等[7]が溶質排除法（液 体クロマトグラフィーではない）によって得た $6 \mathrm{~nm}$ 前後 の值とほぼ一致する. 従って変曲点を排除限界とみなすこ とには意義があると考える．なお笠原等のデータ[4]では 排除限界が綿について PEG 分子量 40,000（直径 12.1nm） または 10,000（直径 6.9nm）となっているが，これは排除 限界の判定方法の違いによるものではないかと考える.

\section{8 Bredereck 等のデータとの比較}

Fig.13 は Fig.11 に示した綿液体アンモニア加工品 2 点 (LA 4-2, 4-3) の Vi の平均值と Fig.12 に示した漂白上り 3 点 (Cotton 2, 3,4) の Vi の平均值をグラフにしたものであ る. Fig.1の Bredereck 等の測定結果と同様, 液体アンモ ニア加工品の方の細孔容積が少ない結果となった.

Fig. 3B は Fig. 2 のデータの排除限界を PEG 分子量 6,450 と仮定して算出したViのグラフである。Fig. 3A と異なり Fig. 13 に近いが, Fig. 13 とは排除限界の值が違うためか 漂白上りと液体アンモニア加工品と差が殆どない。

一方 Bredereck 等のデータ（Fig.1）を本報の観点から見 ると, PEG 分子直径 $4.5 \mathrm{~nm}$ 付近を綿の排除限界と判定す ることも可能である.これは本報での綿の排除限界に近い 值である.

この様に糸の配列状態に配慮すれば，糸束を引き込む 方式による液体クロマトグラフィーは液体アンモニア処 理条件の異なる綿布の解析手段として使用可能と考えら れる.

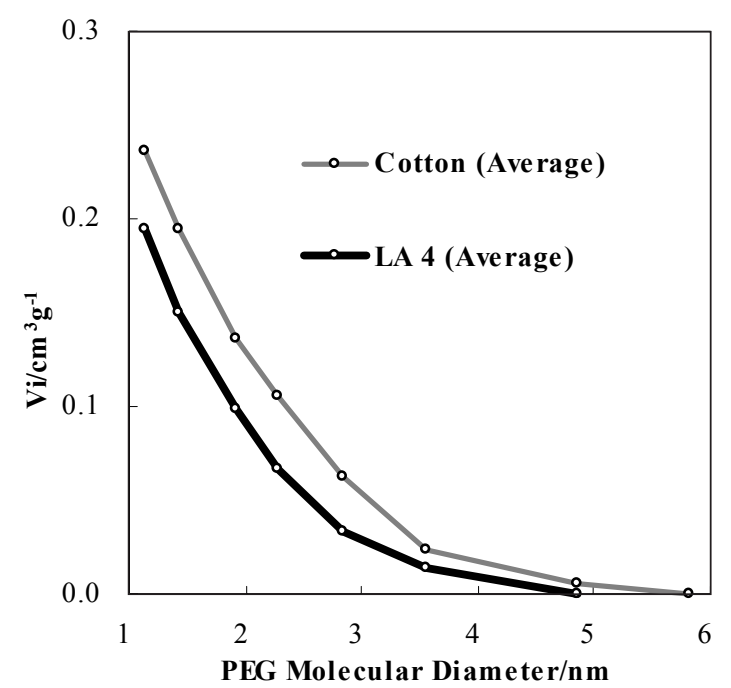

Fig. 13 Average pore volume of cotton, bleached and after liquid ammonia treatment (Ammonia Unit No. 4).

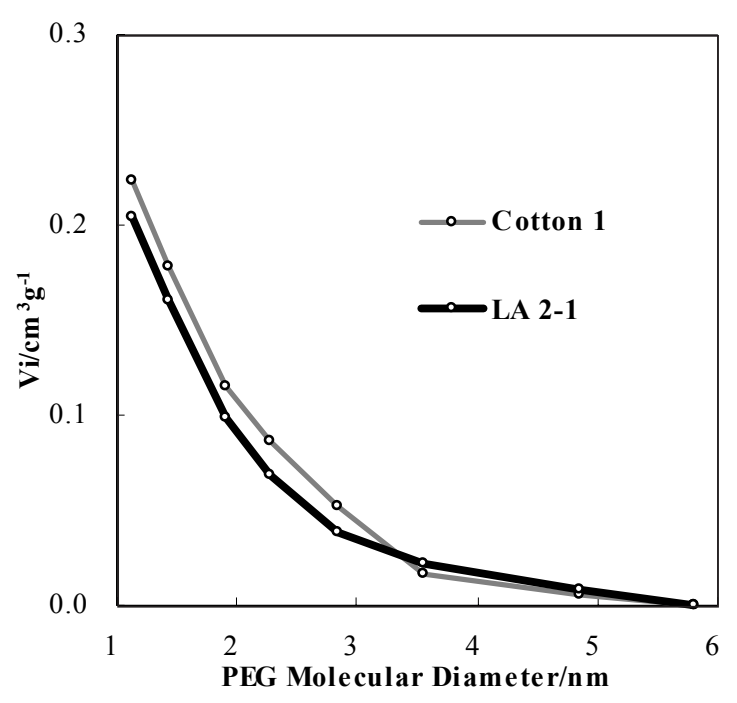

Fig. 3B Pore volume of cotton, bleached and after liquid ammonia treatment. Calculated from the data used in Fig. 2, and assuming the exclusion limit as the PEG molecular weight 6,450 .

\section{9 バナナ繊維の細孔分析}

Fig.14 はバナナ綿 30・70 混紡繊維の細孔容積を, Fig.15 はその分布を示す.バナナ繊維とはバナナの茎の繊維を取 り出したものである. バナナ $100 \%$ の糸は強度不足で紡績 が困難であるため, 30\%の混紡となっているが, 30\%の混 紡品でも明らかにバナナ繊維の特徴のある細孔分布が観 察される.これは、バナナ繊維の構造と関連するものと思 われるが、詳細は今後の検討課題である。

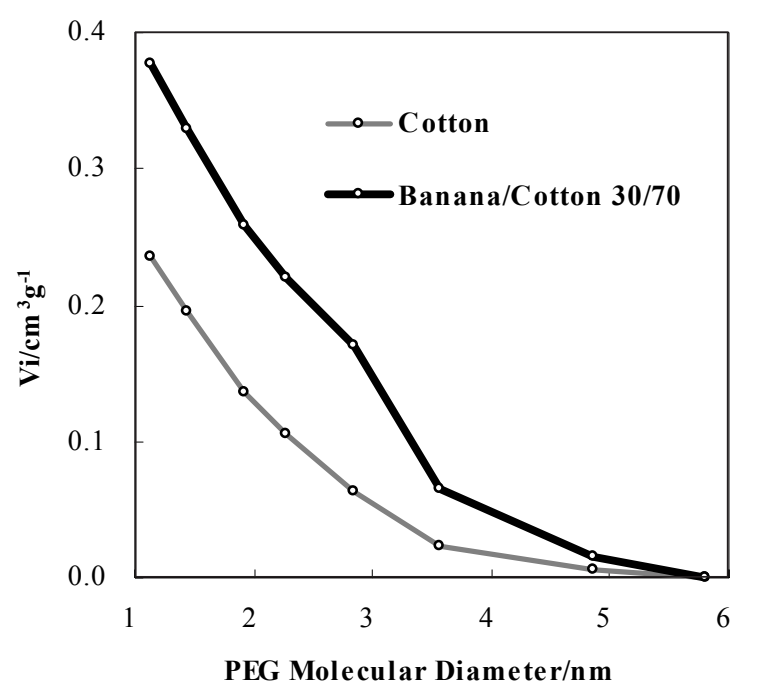

Fig. 14 Pore volume of Banana fiber compared to cotton.

\section{10 綿繊維の品種による細孔分布の違い}

綿糸は通常数種類の品種を混ぜて性能の平準化を図る ので, そのままでは綿の品種の違いは検討できない. そこ で, 特別に単一品種の綿糸を試作してその細孔分布を比較 
した. Fig.16 と Fig.17 はアメリカ綿の代表品種であるサ ンホーキンとアスペロおよびアメリカ長繊維綿の代表品 種であるアメリカンピマを比較したものである.この測定 ではアメリカンピマは非常に特徵的な細孔分布をしてい る. この様な測定結果は今回初めて得られたものであり, 構造の特徵と関連があるものと考えられる.

また測定件数が少ないので, この差が品種全体を表わす ものと直ちには云えないが, 細孔分析によって品種の特定 や品質の判定を行う可能性を示していると考える.

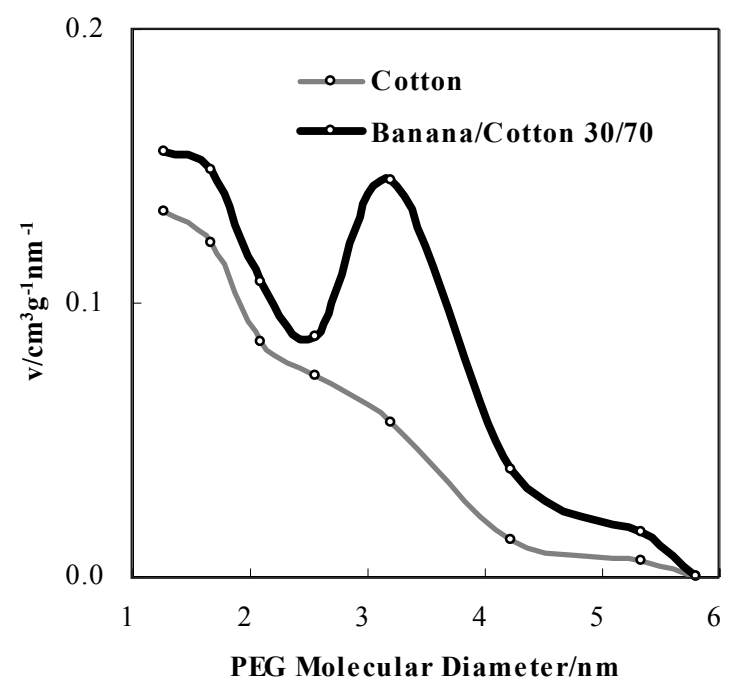

Fig. 15 Pore distribution of Banana fiber.

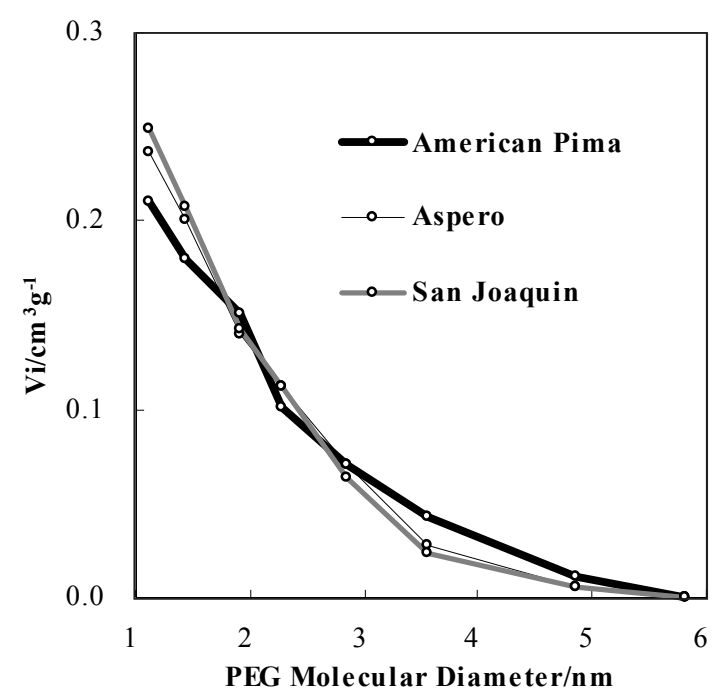

Fig. 16 Pore volume of American Pima, Aspero and San Joaquin.

\section{4. 結 論}

糸を束にしてカラムに引き込み, 液体クロマトグラフ ィーにかけて細孔分布を測定する分析方法は, 試料の種類 によって溶出曲線の状況が異なり, テンセル, レーヨン, リネンは排除限界が分り易いが，50 単糸の綿，特にその 液体アンモニア処理品の場合, 試料の整列状態をよくしな

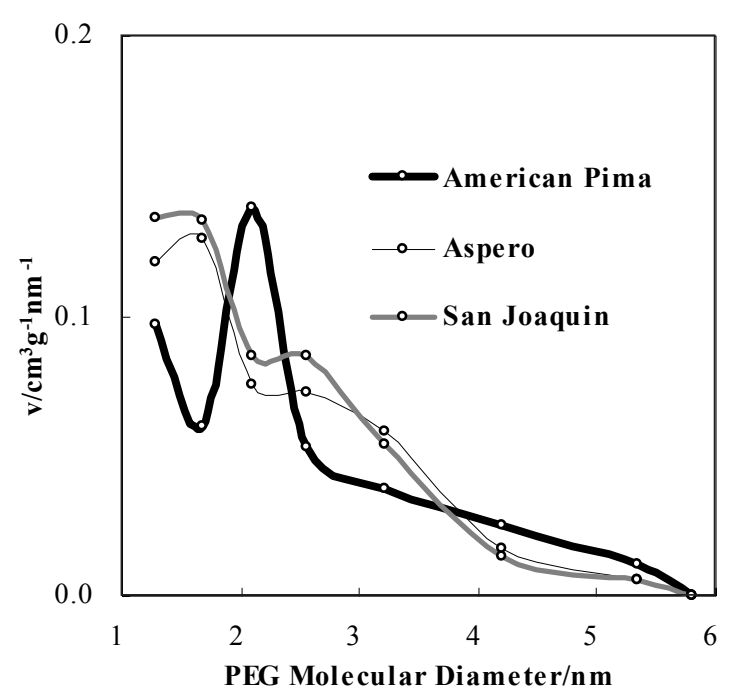

Fig. 17 Pore distribution of American Pima, Aspero and San Joaquin.

いと排除限界が判定できない.この原因は繊維内部の細 孔によるものではなく, 瀻維外部の空隙の多少によるも のと考えられる. 即ち, 糸を束ねた場合, 糸と糸の間に は必ず空隙ができ, その大きさは密着に近い部分の $\mathrm{nm}$ 単 位から大きな空隙の $\mu \mathrm{m}$ 単位まで分布している筈である. 従って, 液体クロマログラフィーで糸の束を分析すると, 繊維内部の細孔のデータと瀻維外部のデータが重なって 検出される.このため, 瀻維内部の細孔の排除限界を過 ぎても, 単純には水平にならず, 外部空隙の分布に応じ て変曲点を示す場合があるものと思われる.

この様な観点で分析結果を見ると, 綛糸であるテンセ ルは, 織物にした時のクリンプがなく外部空隙が少ないた め水平部分が容易に現れ, レーヨンとリネンは織物から経 糸を採取したにも拘らず, 糸が太くクリンプが少ないので 50 単糸綿より水平部分が現れ易かったものと思われる.

これに対し綿（No.5747）は細番手織物であり打込みと 撚りが多いので空隙が多くなり易い上に, 液体アンモニア 処理品は処理の際, クリンプ状態抢よび撚りがセットされ るため, 漂白上がりの綿に比べても空隙が多くなったもの であろう.

纎維外の空隙を減らすため織物から経糸を採取する際, 1 本づつフリーにして撚りを解除し, その後極力平行に並 べると, 溶出曲線に水平に近い部分に続いて変曲点が現れ た. この変曲点を排除限界と判定すると, テンセル, レー ヨン, リネン, 綿いずれについても PEG 分子量 6,450（直 径 $5.8 \mathrm{~nm}$ ）が排除限界と判定され, 文献值[7]とほぼ一致し た. な打同一試料であっても, 作成時期の異なるものは試 料の充填状態が変るためか, 測定曲線が少しづつ異なる. したがって, 1 回の測定で正確な結果を得ることはできず, 数回の測定が必要である.

この様な注意をはらって細孔容積 $\mathrm{Vi}$ を計算すると, 綿 の液体アンモニア処理品について Bredereck 等のデータ とあまり矛盾しないデータが得られた。 
但し Bredereck 等を含め、Rowland 等, Ladisch 等の方 法には本報と同じ繊維間空隙の問題がある筈であると共 に, 使用している綿布及び液体アンモニア処理の条件が異 なるので、厳密な比較ではない. なお Bredereck 等のその 後の報文[5]第 2 図には, 溶出曲線の水平部分に続いて明 らかな低下を示すデータが示されているが、それについて の原因は分らないとし、水平部分の終りを排除限界として 論じている

一方, 各種セルロース繊維及びその加工品についてそ れぞれ特徵的な情報が得られた. 即ち, テンセルのフィブ リル防止品は通常テンセルに比べ膨潤時の細孔容積が明 らかに大きい. 一方, リネンの樹脂加工品は樹脂加工前に 比べ細孔容積が明らかに小さい. 同じ架橋結合でも反応時 の膨潤状態で細孔容積が違うことが分る.

バナナ瀻維を $30 \%$ 混紡した瀻維では混紡割合が少ない にも拘らず,バナナ纎維の特徵的な細孔分布が現れた. ま た綿の単一品種を比較したところ, アメリカンピマがアス ペロやサンホーキンとは異なる細孔分布を示し, 品種の検 定の可能性を示した.

この様に糸束引き込み式の液体クロマトグラフィーに よる細孔分析の手法は, 試料作成に注意することによって, セルロース繊維の細孔分布の解析に有用である. 但し、変 曲点以前の範囲にも繊維外空隙の影響が若干含まれる可 能性があるので、データを解釈する際は類似試料の比較検 討に留めるのが適当であろう. 今後この手法を用いて液体 アンモニア加工等によるセルロース繊維の構造変化につ いて検討する予定である.

\section{謝 辞}

各種綿の試料を提供頂いた日清紡美合工場商品開発セ ンター, テンセルを提供頂いた（株）モーリタンの橋田佳 雅氏, レーヨンを提供頂いた東海染工(株)の大島直久氏, 液体クロマトグラフィーについてご指導頂いた信州大学 の木村睦助教授に感謝申し上げます.

\section{文 献}

1. S. P. Rowland, C. P. Wade, N. R. Bertoniere, J. Appl. Polymer Sci. 29, 3349 (1984).

2. K. Bredereck, A. Blueher, Melliand Textilber. 72, 446 (1991).

3. C. M. Ladisch, Y. Yang, A. Velayudham, M. R. Ladisch, Text. Res. J. 62, 361 (1992).

4. Kasahara, K., Sasaki, H., Donkai, N., Ito, H., Takagisi, T., Sen'i Gakkaishi 58, 332 (2002).

5. K. Bredereck, A. Blueher, Melliand Textilber., 73, 652 (1992).

6. M. Kimizu et al., Fiber Preprints, Japan, Vol. 58, 224 (2003), No. 1(Annual Meeting).

7. S. Abe, S. Ohta, M. Yoshikawa, J. Text. Mach. Soc. Japan, 50, T124 (1997). 